\title{
Second BC drug safety scientist reinstated
}

$\mathrm{T}$

he British Columbia Ministry of Health has renewed ties with Dr. Malcolm Maclure, the BC Academic Chair in Patient Safety and a professor at the University of $\mathrm{BC}$, who was dismissed, along with six other scientists and officials, from his half-time job as the province's drug research director in July 2012. In a statement on July 18, 2014, the ministry said Maclure is "renowned for his expertise" in drug study methodologies and has been retained as a consultant with full access to health care data. "This represents a renewal of my collaboration with the Ministry of Health," said Maclure.

The ministry's statement clears Maclure's name amidst a scandal that stalled numerous safety probes into many widely used drugs and harmed $\mathrm{BC}$ 's once-renowned drug research system. However, the ministry makes no mention of its actions in dismissing Maclure, let alone of any wrongdoing in harming his reputation while dramatically curbing independent drug research.

Those omissions have prompted criticism from Dr. David Henry, the executive co-lead of the Canadian Network for Observational Drug Effect Studies, a network of provincial data centres and investigators who perform drug safety analyses.

"I think the actions taken by the ministry were inappropriate and wrong," Henry said. "Maclure should be fully cleared on any wrongdoing whatsoever. This was a bit of a witch hunt. There should be some recognition that someone in the ministry triggered a campaign here. There was wrongdoing and people suffered. Some very badly."

Maclure and the others were dismissed during an investigation that

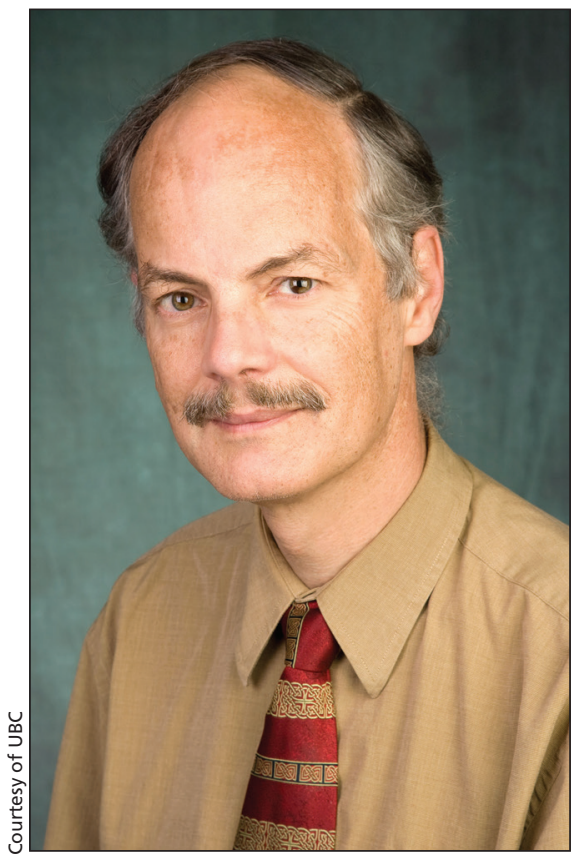

Dr. Malcolm Maclure was BC's drug research director when he was dismissed by the BC Ministry of Health in July 2012.

former health minister Margaret MacDiarmid said involved alleged potential conflicts of interest, contracting irregularities and inappropriate data management. In September 2012, MacDiarmid, who subsequently lost her seat in a provincial election and was replaced as minister, said police were investigating.

Following his dismissal, Maclure filed a lawsuit alleging the ministry behaved "recklessly" and that his "unlawful" dismissal was done "without regard or concern to causing damage" to his reputation. Maclure said the dismissal has resulted in nightmares, humiliation, anxiety, memory loss and lack of sleep. "The reputation of scientists is extremely important to them,"
Maclure told CMAJ. The experience was "like an interruption in the meaningfulness of my life."

When he was dismissed, Maclure's role in studies using BC PharmaNet data to assess the safety of antipsychotic drugs and Alzheimer drugs, as well as on a project to help physicians reform their prescribing patterns, was frozen. In his new role as a consultant, Maclure says, "I expect to resume working on prescribing improvement studies soon. The drug safety studies that were stopped are restarting, one by one.

An interview with a spokesperson from the ministry was not granted.

Maclure would not discuss whether the ministry will give him financial compensation for dismissing him and declined to discuss the ministry's explanation for its actions in his dismissal beyond acknowledging that the governance of relationships between independent scientists and politicians and bureaucrats "is so hard to get right." When scientists agree to work with governments, Maclure warned, "you have to be prepared for things not always to move in a straight line."

The hiring of Maclure as a consultant follows on the reinstatement in March of Robert Hart as director of data access, research and stewardship within the ministry. Two other researchers who were dismissed have filed lawsuits that have yet to be resolved. Three other ministry officials who were also dismissed went through a labour grievance process, but were not reinstated. One of them, Roderick MacIsaac, committed suicide in January 2013. - Paul Christopher Webster, Toronto, Ont.

CMAJ 2014. DOI:10.1503/cmaj.109-4860 